\title{
HERBACEOUS SUCCESSION AFTER BURNING OF CUT WESTERN JUNIPER TREES
}

\author{
Jon D. Bates ${ }^{1,2}$ and Tony J. Svejcar ${ }^{1}$
}

\begin{abstract}
The expansion of western juniper (Juniperus occidentalis spp. occidentalis Hook.) in the northern Great Basin has resulted in the wide-scale conversion of sagebrush-steppe communities to juniper woodlands. Prescribed fire and mechanical cutting are the 2 main methods used to remove juniper and restore sagebrush steppe. Mechanical treatments commonly leave cut juniper on site. Disadvantages of leaving cut juniper are the increased fuel hazard and the potential for increased establishment and growth of invasive species. This study evaluated the response of herbaceous plants to winter burning of cut western juniper. Vegetation response was compared among 2 burning treatments (burning trees the first winter after cutting and burning the second winter after cutting), a control (cut-unburned juniper), and the interspace between cut trees. To minimize fire impacts to herbaceous perennials, cut trees were burned in the winter when soils and ground litter were frozen and/or soils were at field capacity. Only felled trees were burned, as fire did not carry into interspaces or litter mats around western juniper stumps. We hypothesized that winter season burning would increase herbaceous perennials and would reduce cheatgrass establishment when compared to the cut-unburned control. After 10 years, total herbaceous and perennial grass cover was 1.5- to 2-fold greater, respectively, in burned treatments compared to cut-unburned controls. Perennial grass density was $60 \%$ greater in the burned treatments than in the cut-unburned treatment and the interspace. Cheatgrass cover was twice as great in the control than in the 2 burn treatments and the interspace. We concluded that burning cut western juniper when soils were wet and frozen in winter enhanced community recovery of native perennials compared to leaving cut juniper unburned.
\end{abstract}

Key words: Bromus tectorum, annual grass, Juniperus occidentalis, litter, fire, Thurber's needlegrass, squirreltail.

The expansion of western juniper (Juniperus occidentalis spp. occidentalis Hook.) in the northern Great Basin has resulted in landscape-level conversions of sagebrush-steppe, riparian, and aspen communities to juniperdominated woodlands (Miller et al. 1999, 2000, Wall et al. 2001). Western juniper woodlands have increased nearly $90 \%$ since settlement of the region began in the 1860s (Miller et al. 2005). Woodlands now occupy 3.5 million ha in eastern Oregon, northeastern California, northern Nevada, and southwestern Idaho. The main cause of the expansion has been attributed to reductions in fire disturbances as a consequence of historic grazing and fire suppression (Burkhardt and Tisdale 1969, Miller and Rose 1995). Juniper invasion reduces shrubsteppe productivity (Vaitkus and Eddleman 1987, Bates et al. 2000, Miller et al. 2000), alters hydrologic and nutrient cycles (Buckhouse and Mattison 1980, Josiatis 1990, Bates et al. 2000, 2002, Roberts and Jones 2000, Pierson et al. 2007), and ultimately causes decreases in wildlife habitat (Miller et al. 2005, Noson et al. 2006). Efforts to control western juniper and restore sagebrush-steppe, riparian, and aspen communities have become a major focus of ecosystem management in the region.

Prescribed fire, mechanical cutting, and a combination of these treatments have been the main methods used to control western juniper (Miller et al. 2005). Fire remains a viable management option for western juniper removal in woodlands that are in early (Phase I) to midsuccessional (Phase II) stages, when sufficient and continuous surface $(0-1 \mathrm{~m})$ fuels are present (Miller et al. 2005). In late successional (Phase III) woodlands, surface fuels are typically not adequate to sustain fire and remove trees; therefore, these woodlands have mainly been cut with chainsaws (Miller et al. 2005). Cutting treatments have commonly prescribed leaving cut western juniper on site. Evidence suggests that retaining cut western juniper or other pinyon-juniper species stabilizes site hydrology by reducing runoff and erosion, encouraging the establishment of perennial

\footnotetext{
${ }^{1}$ USDA-Agricultural Research Service and Oregon Agricultural Experiment Station, Eastern Oregon Agricultural Research Center, 67826-A Hwy. 205, Burns, OR 97720.

2E-mail: jon.bates@oregonstate.edu
} 
grasses and retaining site nutrient capital (Jacobs and Gatewood 1999, Brockway et al. 2002, Pierson et al. 2007). A major disadvantage to leaving cut western juniper in place is the increased fuel hazard, particularly during the first 2-3 years posttreatment when dried leaves remain on downed trees. Another disadvantage to retaining cut trees and debris after mechanically treating western juniper is that these areas create ideal microsites for invasion by undesirable nonnative annual grasses and may slow recovery of desired native species (Young et al. 1985, Bates et al. 2005, 2007a,). Recently, efforts have shifted to removing cut western juniper by burning to reduce potential fire hazards.

In 1997 we established a study to evaluate the response of herbaceous vegetation to burning cut western juniper. Herbaceous dynamics were compared among 2 winter burning treatments (burning trees the first winter after cutting and burning the second winter after cutting), a control (cut and unburned juniper), and the interspace between cut trees. Burning was done in the winter or early spring when soils and ground litter were frozen and/or thoroughly wetted to minimize the impacts of fire to perennial herbaceous vegetation. Winter burning was selected over fall burning because burning in the fall may produce more severe impacts to native vegetation. Fall burning of felled juniper produces temperatures sufficient to kill most herbaceous species (Gifford 1981), especially perennial grasses, and can increase abundance of exotic species (Haskins and Gehring 2004). Fall burning of cut western juniper in quaking aspen (Populus tremuloides Michx.) woodlands when soils and ground litter were dry severely impacted herbaceous vegetation resulting in the complete removal of perennial bunchgrasses and a high percentage of perennial forbs (Bates et al. 2006). Early spring burning of cut western juniper in aspen woodlands when soils and ground litters were saturated and frozen caused no mortality of perennial herbaceous vegetation (Bates et al. 2006). Thus, we hypothesized that burning cut western juniper in the winter would cause little measurable mortality to existing native herbaceous perennials, resulting in faster and greater recovery of these species, and would reduce the potential for introduced annual grasses to establish and increase when compared to cut-unburned controls.

\section{Methods}

Study Site

The study site was on Steens Mountain, southeastern Oregon $\left(118^{\circ} 36^{\prime} \mathrm{E}, 42^{\circ} 55^{\prime} \mathrm{N}\right)$. Elevation at the site is $1575 \mathrm{~m}$ and aspect is west facing (11\% slope). The majority of annual precipitation falls between November and late May. Annual precipitation (1 October-30 September) at Malheur National Wildlife Refuge weather station, located $30 \mathrm{~km}$ northwest $(1250 \mathrm{~m})$ of the study site, has averaged 254 mm over the past 64 years (Fig. 1). Soils are mainly Typic Vitrixerand with inclusions of a Typic Calcixeroll that are underlain by a welded volcanic ash tuff, which restricts root penetration at $40 \mathrm{~cm}$.

The site was dominated by 90 -year-old western juniper woodland. Juniper had fully occupied this site as indicated by limited lateral and terminal leader growth, crown lift, and lack of further juniper recruitment (Bates et al. 2000). Juniper canopy cover averaged $30.5 \%$, and tree density averaged 283 trees $\cdot \mathrm{ha}^{-1}$. Sagebrush was eliminated from the site by juniper interference, though previous shrub occupancy was evident by the presence of numerous shrub skeletons. The dominant shrub prior to juniper encroachment was basin big sagebrush (Artemisia tridentata ssp. tridentata [Beetle \& Young] Welsh). Herbaceous cover averaged $5.5 \%$. Bare ground and rock in the interspace was about $95 \%$. Understory composition was a mix of native grasses and native and nonnative forbs. Sandberg's bluegrass (Poa secunda J. Presl.) and pale alyssum (Alyssum alyssoides L.) were the most common grass and forb species. Other characteristic species were bottlebrush squirreltail (Elymus elymoides [Raf.] Swezey), bluebunch wheatgrass (Pseudoroegeneria spicata [Pursh] A. Löve), Thurber's needlegrass (Achnatherum thurberianum [Piper] Barkworth), and basalt milkvetch (Astragalus filipes Torr.). Cheatgrass (Bromus tectorum L.) was present $(<0.1 \%$ cover $)$ and primarily grew beneath juniper canopies.

This particular site has been used to evaluate long-term vegetation dynamics after mechanical cutting of western juniper in several earlier studies (Bates et al. 2005, 2007a). These past studies demonstrated that cutting of western juniper was effective at increasing understory biomass, density, cover, and diversity (Bates et al. 2005), and that succession 


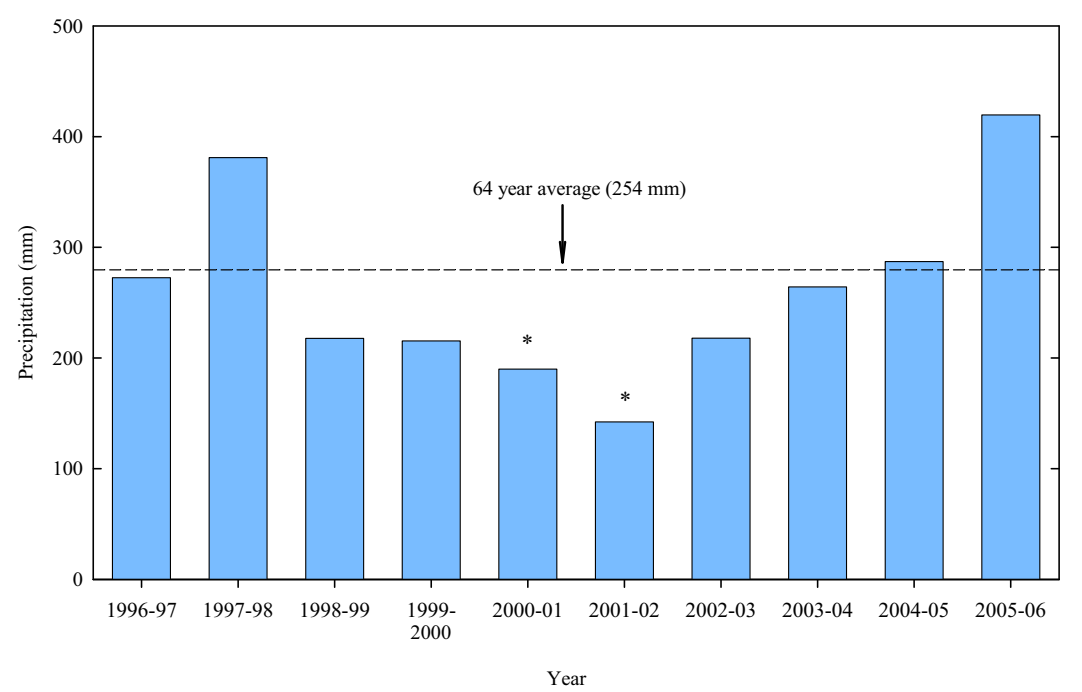

Fig. 1. Annual precipitation (mm) for years 1997-2006 and the long-term average at the Malheur National Wildlife Refuge weather station $(1250 \mathrm{~m})$, located $29 \mathrm{~km}$ northwest of the study site on Steens Mountain, Oregon.

dynamics were influenced by microsite (Bates et al. 2007a). For example, under cut juniper, cover and density of herbaceous species associated with interspaces were reduced and species characteristic of canopy locations increased (Bates et al. 2007a). These studies also reported that significant cheatgrass response was delayed until 5-6 years after tree cutting and was confined to areas of litter accumulation beneath cut trees and in old canopy litter mats. However, by the 12 th year after tree cutting native perennial bunchgrasses were dominant and cheatgrass was only a minor component of the study sites.

\section{Experimental Design}

The experimental design was a randomized block with 5 blocks and 3 treatments (Peterson 1985). Blocks were 1.5 ha in size (treatments within each block occupied 0.5 ha). Baseline vegetation characteristics were measured in July 1997. In September 1997, all trees were cut using chainsaws and left in place. Posttreatment vegetation was measured in midMay 1998-2001 and 2006. Livestock were excluded during the study.

Cut juniper treatments were the following: a control (cut-unburned juniper), cut trees burned the first winter after cutting (1st-year burn), and cut trees burned the second winter after cutting (2nd-year burn; Fig. 2). The areas influenced by cut trees are equivalent to debris locations described by Bates et al. (2007a). Cut tree (debris) locations were former interspace areas that were covered by trees after cutting and were identical to the interspace in species composition and canopy cover prior to cutting. All treatments' measurements were collected on former interspace zones that were covered with felled juniper trees. Interspaces not covered by trees were measured across each block in cut-unburned and cut-burned treatments.

The 1st-year burn treatment was applied on 11 March 1998. The 2nd-year burn treatment was applied on 20 February 1999. Gravimetric soil water $(0-10 \mathrm{~cm})$ and fuel (herbaceous fine fuels and ground litter) moisture were measured on the day of fire application. Fuel moisture and soil water were determined by drying fuel and soil, separately, at $100{ }^{\circ} \mathrm{C}$ to a constant weight. Weather data (humidity, wind speed, and temperature) were recorded on the day of fire applications. Burn conditions are provided in Table 1. The criteria for burning were that (1) soils and surface litter under cut trees were wet (at field capacity) and preferably frozen, and (2) suspended juniper leaf litter was dry $(<20 \%$ water content). Downed juniper covered between $25 \%$ and $35 \%$ of the area, so care had to be taken in selecting days when there was minimal wind to reduce the possibility of fire spreading into adjacent treatments. Burning was done using drip torches containing a 60:40 mixture of diesel and unleaded gas. In 


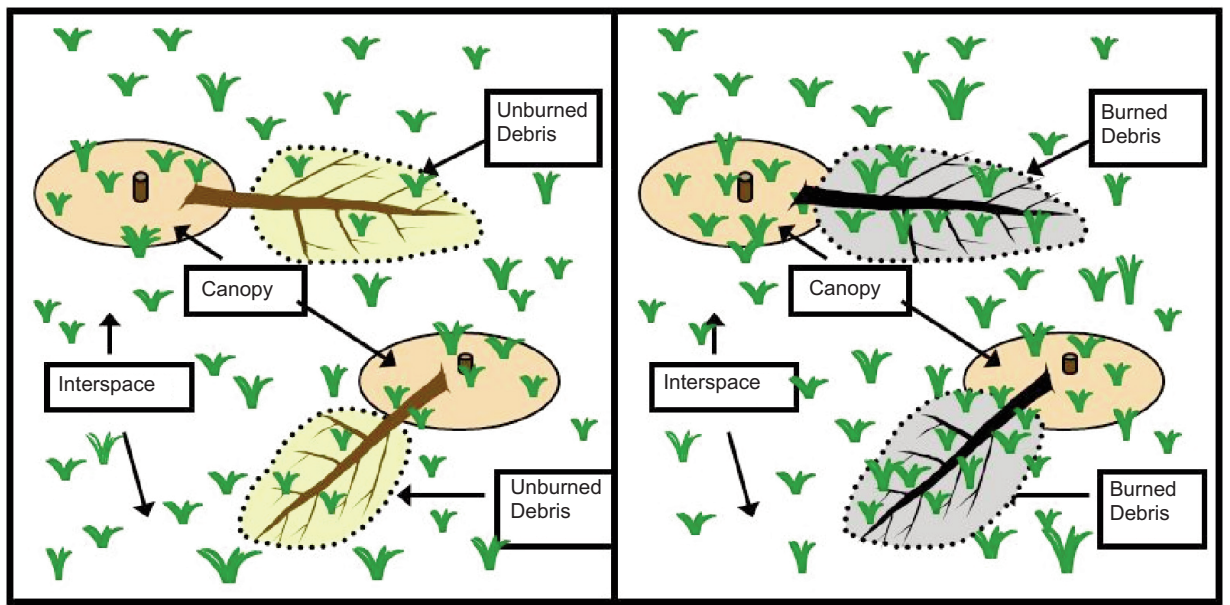

Fig. 2. Examples of unburned and burned cut western juniper treatments on Steens Mountain, Oregon. Also shown are location delineations for the cut juniper treatments (debris, interspace, and canopy). The debris locations are former interspaces that were covered by trees after cutting. The debris location was the only area that burned in the cut-andburn treatments. Interspaces are open areas between canopy and debris locations. The canopy location is the litter mat beneath precut western junipers, and herbaceous vegetation in the canopy areas was not measured in this study.

TABLE 1. Weather and water content conditions for 1st-year and 2nd-year burns in cut juniper woodlands, Steens Mountain, Oregon. Water content and soil temperatures were measured under cut trees prior to burning.

\begin{tabular}{lcc}
\hline & 11 March 1998 burn & 20 February 1999 burn \\
\hline Weather and soil variables & & $3-7$ \\
Air temperature $\left({ }^{\circ} \mathrm{C}\right)$ & $8-16$ & $36-72$ \\
Relative humidity $(\%)$ & $41-55$ & $6-16$ \\
Wind speed $(\mathrm{kph})$ & $10-13$ & -3.2 \\
Soil temperature $\left(5 \mathrm{~cm},{ }^{\circ} \mathrm{C}\right)$ & 4.4 & 31 \\
Water content $(\%)$ & 35 & 109 \\
Soil $(0-10 \mathrm{~cm})$ & 107 & 8 \\
Surface juniper litter $(0-5 \mathrm{~cm})^{\mathrm{a}}$ & 7 & \\
Suspended juniper needles $(>5 \mathrm{~cm})$ & & \\
\hline
\end{tabular}

a Water content of surface juniper litter exceeded $100 \%$, probably because of accumulations of snow or frost in samples.

the burn treatments, fire was confined to areas occupied by the cut trees and did not burn into interspaces or around the litter mats under former juniper canopies. Litter moisture of the older litter mats of former juniper canopies was too high for fires to burn and consume the mats.

Fire severity was estimated using an index of juniper consumption and percentage of perennial grasses killed. The severity categories were light (1\%-29\% of surface litter consumed, $<20 \%$ of the perennial grasses killed, and $<100 \%$ of suspended 1-hour fuels [leaves and twigs, $<6.3 \mathrm{~mm}$ diameter] consumed), moderate $(30 \%-79 \%$ of surface litter consumed, $<20 \%-70 \%$ perennial grasses killed, $<100 \%$ of suspended debris up to 10-hour fuels $[<25$ $\mathrm{mm}$ diameter] consumed), and high ( $>80 \%$ of surface litter consumed, $>70 \%$ perennial grasses killed, only trunks and branches [ $>25$ mm diameter] of downed juniper remaining).

\section{Understory Sampling}

Herbaceous canopy cover and density by species were measured using $0.2-\mathrm{m}^{2}$ frames $(0.4 \times 0.5 \mathrm{~m})$ in 1997-2001 and 2006. Ground cover was visually estimated for the following categories: herbaceous species, bare ground, rock, litter (juniper and herbaceous), and biotic crust. Density of herbaceous perennials was measured by counting all individuals within the frames. Density of the cheatgrass was measured by counting individuals in a $0.05-\mathrm{m}^{2}$ nested plot $(0.1 \times 0.5 \mathrm{~m})$ within each frame. For the cut and cut-and-burn treatments, 
TABle 2. $P$-values for herbaceous cover and density comparing burned and unburned treatments and interspace in cut juniper woodlands, Steens Mountain, Oregon, 1997-2001 and 2006. Asterisks $\left.{ }^{*}\right)$ indicate significant main effect and year $\times$ treatment interactions at $P<0.05$.

\begin{tabular}{|c|c|c|c|c|c|c|}
\hline \multirow[b]{2}{*}{ Response variable } & \multicolumn{3}{|c|}{ Cover } & \multicolumn{3}{|c|}{ Density } \\
\hline & Year & Treatment & Year $\times$ Treatment & Year & Treatment & Year $\times$ Treatment \\
\hline \multicolumn{7}{|l|}{ GROUND COVER } \\
\hline Total herbaceous & $0.0001 *$ & $0.0001^{*}$ & $0.0930^{*}$ & - & - & - \\
\hline Bare ground/rock & $0.0001 *$ & $0.0001 *$ & $0.0001 *$ & - & - & - \\
\hline Juniper litter & $0.0001 *$ & $0.0001 *$ & $0.0001 *$ & - & - & - \\
\hline Herbaceous litter & $0.0001^{*}$ & $0.0001 *$ & $0.0001^{*}$ & - & - & - \\
\hline Moss/crust & 0.5402 & 0.3629 & 0.4284 & - & - & - \\
\hline \multicolumn{7}{|l|}{ FUNCTIONAL GROUP } \\
\hline Sandberg's bluegrass & $0.0001 *$ & $0.0001 *$ & $0.0330^{*}$ & $0.0001^{*}$ & $0.0001^{*}$ & 0.7813 \\
\hline Perennial grass & $0.0001^{*}$ & $0.0001 *$ & 0.0833 & $0.0001 *$ & $0.0055^{*}$ & 0.0001 \\
\hline Cheatgrass & $0.0001^{*}$ & $0.0074 *$ & $0.0007^{*}$ & $0.0001 *$ & $0.0163 *$ & $0.0077^{*}$ \\
\hline Perennial forb & $0.0391 *$ & $0.0010^{*}$ & $0.0073^{*}$ & 0.7274 & $0.0018 *$ & 0.3546 \\
\hline Annual forb & $0.0001 *$ & $0.0001^{*}$ & $0.0063 *$ & - & - & - \\
\hline \multicolumn{7}{|l|}{ SPECIES } \\
\hline Bluebunch wheatgrass & $0.0001^{*}$ & $0.0001 *$ & 0.1550 & $0.0001^{*}$ & $0.0393 *$ & 0.9631 \\
\hline Squirreltail & $0.0001^{*}$ & $0.0252 *$ & 0.2203 & $0.0001 *$ & $0.0009 *$ & $0.0032 *$ \\
\hline Thurber's needlegrass & $0.0001^{*}$ & $0.0001^{*}$ & 0.2440 & $0.0001 *$ & $0.0490 *$ & $0.0069 *$ \\
\hline Pale agoseris & $0.0129 *$ & 0.0858 & 0.2920 & $0.0004 *$ & 0.1773 & 0.1030 \\
\hline Basalt milkvetch & $0.0027^{*}$ & 0.3389 & 0.1095 & 0.0741 & 0.1424 & 0.1084 \\
\hline Mariposa lily & 0.2924 & 0.4217 & 0.2603 & $0.0012 *$ & 0.1828 & 0.0804 \\
\hline Western hawksbeard & $0.0001^{*}$ & $0.0058 *$ & 0.3850 & $0.0037^{*}$ & 0.5097 & 0.0841 \\
\hline Donnell’s lomatium & $0.0340^{*}$ & $0.0016^{*}$ & 0.3555 & $0.0212 *$ & $0.0007^{*}$ & 0.2149 \\
\hline Tailcup lupine & 0.1617 & $0.0067 *$ & 0.2947 & 0.4879 & $0.0391 *$ & 0.5484 \\
\hline Other perennial forbs & 0.6133 & $0.0028 *$ & 0.7426 & $0.0160 *$ & 0.6982 & 0.7942 \\
\hline Pale alyssum & $0.0001 *$ & $0.0006^{*}$ & $0.0008 *$ & - & - & - \\
\hline Epilobium & $0.0001 *$ & $0.0005^{*}$ & $0.0147 *$ & - & - & - \\
\hline Prickly lettuce & $0.0001 *$ & $0.0001^{*}$ & $0.0001 *$ & - & - & - \\
\hline Microseris & $0.0001^{*}$ & $0.0001^{*}$ & $0.0012 *$ & - & - & - \\
\hline Line-leaf phacelia & $0.0001^{*}$ & $0.0001^{*}$ & $0.0001 *$ & - & - & - \\
\hline
\end{tabular}

herbaceous plants were measured under 10 randomly selected trees in each treatment replicate (Fig. 2). Under the trees, 4 randomly located frames were measured for herbaceous cover and density (40 per treatment replicate). Interspace measurements were randomly located in remaining open areas between cut trees (40 frames per treatment replicate). Herbaceous vegetation was initially measured in the litter mats or canopy locations beneath the precut western juniper tree in 1997. In subsequent years we discontinued measurements in this area because the fires did not burn in the old canopy mounds. The rationale for not continuing measurements in the canopy areas was that herbaceous dynamics would likely be similar to what was reported for canopy locations by Bates et al. (2007a). Bates et al. (2007a) reported that cheatgrass and perennial grasses codominated canopy areas 6 years after cutting; however, by the 12th year of the study perennial grasses dominated canopy areas as cheatgrass declined in cover and biomass. In the current study, observations in 2007 indicated that perennial grasses and annual grasses were codominating in canopy locations in the burned and unburned treatments.

\section{Statistical Analysis and Data Organization}

Analysis of variance was used to test for treatment effects on herbaceous cover (species and functional group) and density (species and functional group). Functional groups were composed of Sandberg's bluegrass, deep-rooted perennial bunchgrasses (e.g., Thurber's needlegrass, bluebunch wheatgrass, and bottlebrush squirreltail), cheatgrass, perennial forbs, and annual forbs. Cover and density response variables were analyzed using a repeated-measure ANOVA for a randomized complete block model (SAS Institute, Inc. 2002). The model included block ( 5 blocks, df $=4$ ), year (19972001 and 2006, df $=5$ ), treatment (cut-unburned, interspace, 1st-year burn, 2nd-year burn; $\mathrm{df}=3$ ), and year $\times$ treatment interaction $(\mathrm{df}=15$, error term $\mathrm{df}=92)$. Because of a strong year effect, years were also analyzed 
separately to simplify presentation of the results and to assist in explaining interactions. Data were tested for normality using the SAS univariate procedure. Data not normally distributed were arcsine square-root transformed to stabilize variance. Back-transformed means are reported. Statistical significance was set at $P<0.05$ and means were separated using Fisher's protected LSD.

\section{RESUlTS}

\section{Ground Cover}

Values for ground cover response variables indicated differences among treatments across the sampling period (Table 2). Herbaceous cover increased in all treatments between 1997 and 2006 (Fig. 3A). However, in 2006 herbaceous cover was less in the cut-unburned treatment than in the other treatments. Juniper litter was less in the interspace than in all the cut (burned and unburned) juniper treatments (Fig. 3B). Under cut juniper (burned and unburned), juniper litter initially increased and then declined over time. Juniper litter was greatest in the cut-unburned treatment followed in order by the 2nd-year burn and 1styear burn treatments. Herbaceous litter increased in all the treatments over time (Fig. 3C). By 2006, herbaceous litter was greatest in the cut-unburned and 2nd-year burn treatments followed in order by the 1st-year burn treatments and interspace. In 2006, we observed that herbaceous litter in the cut-unburned treatment was mainly composed of the previous year's growth of cheatgrass. Herbaceous litter in the other treatments was mainly composed of earlier years' growth of perennial grasses. Because tree cutting increased juniper litter, all the cutting treatments had less bare ground than the interspace (Fig. 3D). Bare ground declined over time in the interspace as litter and herbaceous cover increased. Bare ground in the cut-unburned treatment was less than both cut-and-burn treatments.

\section{Functional Group Cover and Density}

Functional group measurements were useful in detecting plant compositional changes among the treatments. Year $\times$ treatment interactions were significant for density and cover of most functional-group response variables (Table 2). Perennial grass cover increased in all treatments over time. However, after the 3rd year post- cutting (2000), perennial grass cover was less in the cut-unburned treatment than in both cut-and-burn treatments and the interspace (Fig. 4A). By 2006, perennial grass cover was nearly twice as great in the 1st-year and 2ndyear burn treatments and the interspace compared to the cut-unburned treatment. Sandberg's bluegrass cover in the cut-unburned treatment declined over time and tended to be less there than in one or more of the other treatments in most years (Fig. 4B). In 2006, Sandberg's bluegrass cover was nearly 5 times greater in the interspace and 1st-year burn treatments than in the cut-unburned treatment. Perennial forb cover in the cutunburned treatment was less than it was in one or more of the cut-and-burn treatments between 1998 and 2000 (Fig. 4C). However, in no treatment did perennial forb cover increase above pretreatment levels. In 2006, treatments did not differ in perennial forb cover. Cheatgrass cover increased in all treatments by 2000 or 2001 (Fig. 4D). Cheatgrass increased similarly among the cut-unburned and both cut-and-burn treatments in the first 4 growing seasons (1998-2001). However, in 2006, cheatgrass cover was nearly 3 times higher in the cut-unburned treatment than it was in the other treatments. Annual forb cover varied among years, and until 2006 no treatment differences were measured (Fig. 4E). In 2006, annual forb cover was 4.5 and 6 times greater in the interspace and 1st-year burn treatment compared to the cut-unburned treatment.

Functional-group density response was similar to treatment relationships, and it trends as described above for functional-group cover. By 2006, Sandberg's bluegrass density had declined in all treatments except the 1st-year burn (Fig. 5A). Sandberg's bluegrass density in 2000, 2001, and 2006 was less in the cutunburned treatment than in the interspace and both cut-and-burn treatments. Perennial grass density increased in all treatments by the end of the study (Fig. 5B). By 2006, perennial grass density was greater in both cutand-burn treatments than in the cutunburned treatment and the interspace. Cheatgrass density increased in 2000 and 2001 in all treatments (Fig. 5C). By 2006, cheatgrass density was twice as high in the cutunburned treatment than in the interspace and both cut-and-burn treatments. Perennial 


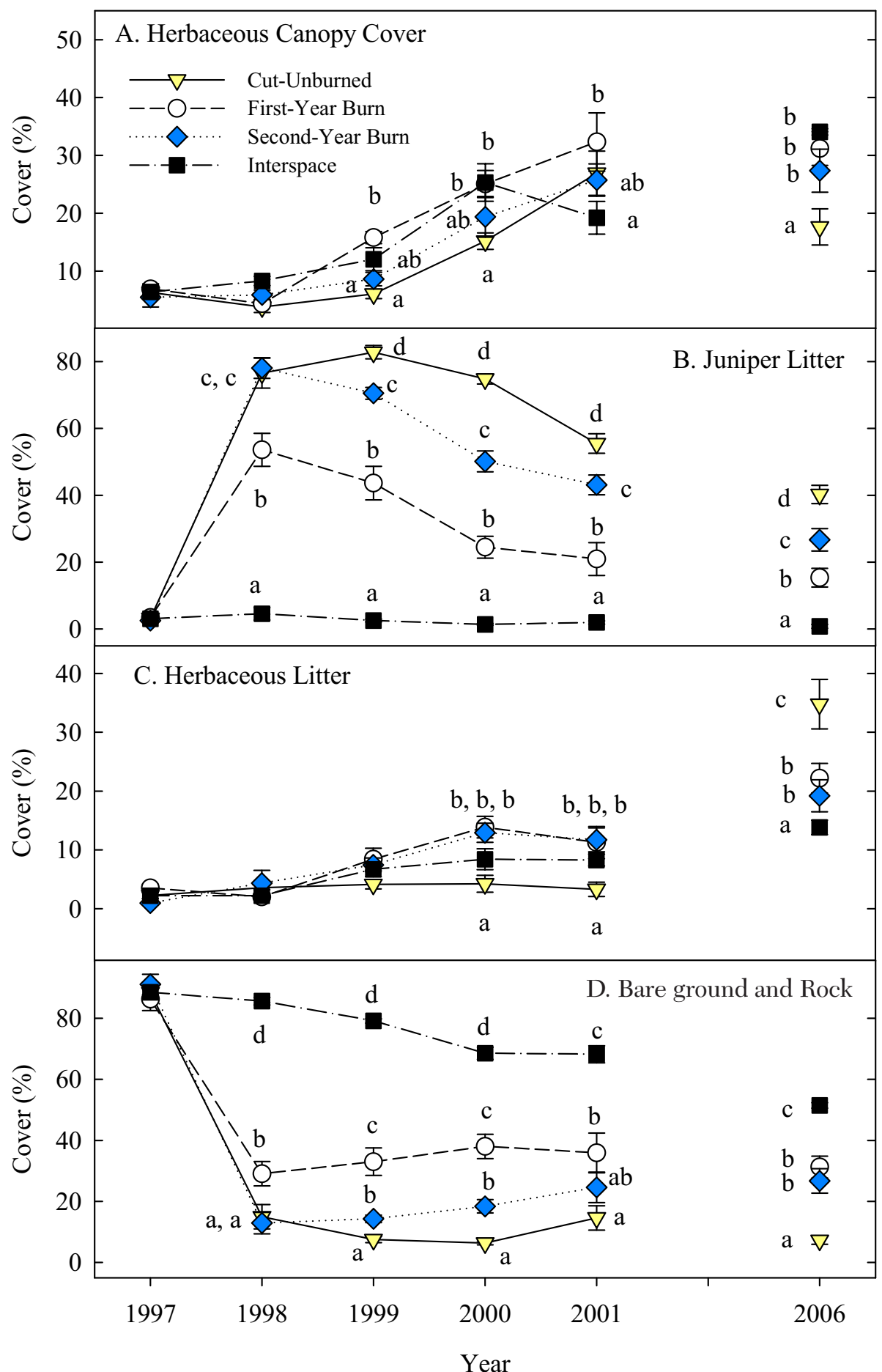

Fig. 3. Ground cover $(\%)$ response variables for the debris treatments (1st-year burn, 2nd-year burn, cut-unburned) and interspace on Steens Mountain, Oregon: A, herbaceous cover; B, herbaceous litter; C, juniper litter; D, bare ground. Data are means with bars representing one standard error. Significant differences $(P<0.05)$ among the treatments are indicated by different lowercase letters. 


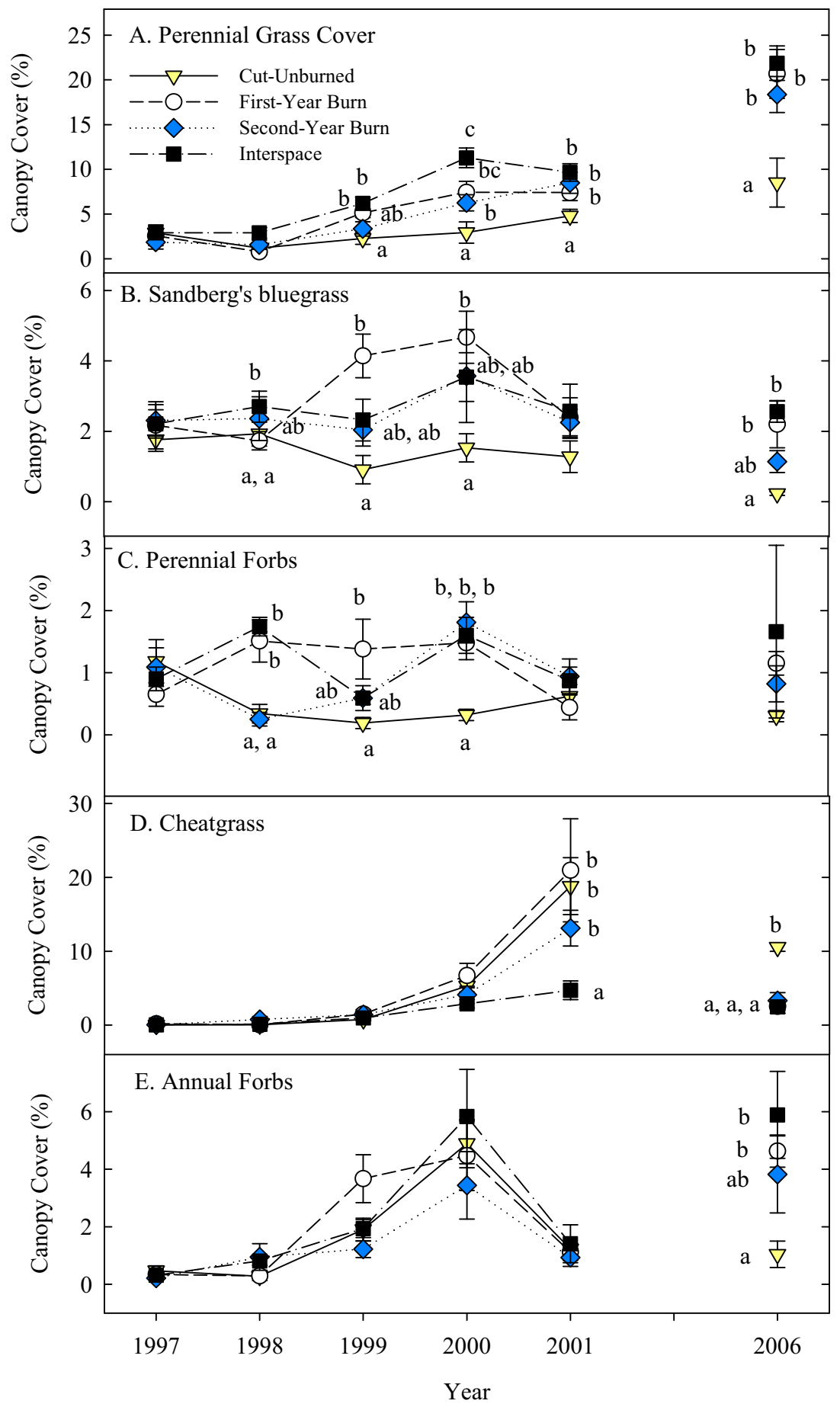

Fig. 4. Functional group cover $(\%)$ for the debris treatments (1st-year burn, 2nd-year burn, cut-unburned) and interspace on Steens Mountain, Oregon: A, perennial bunchgrasses; B, Sandberg's bluegrass; C, perennial forbs; D, cheatgrass; $\mathrm{E}$, annual forbs. Data are presented as means with bars representing one standard error. Significant differences $(P$ $<0.05$ ) among treatments for the response variables are indicated by different lowercase letters. 


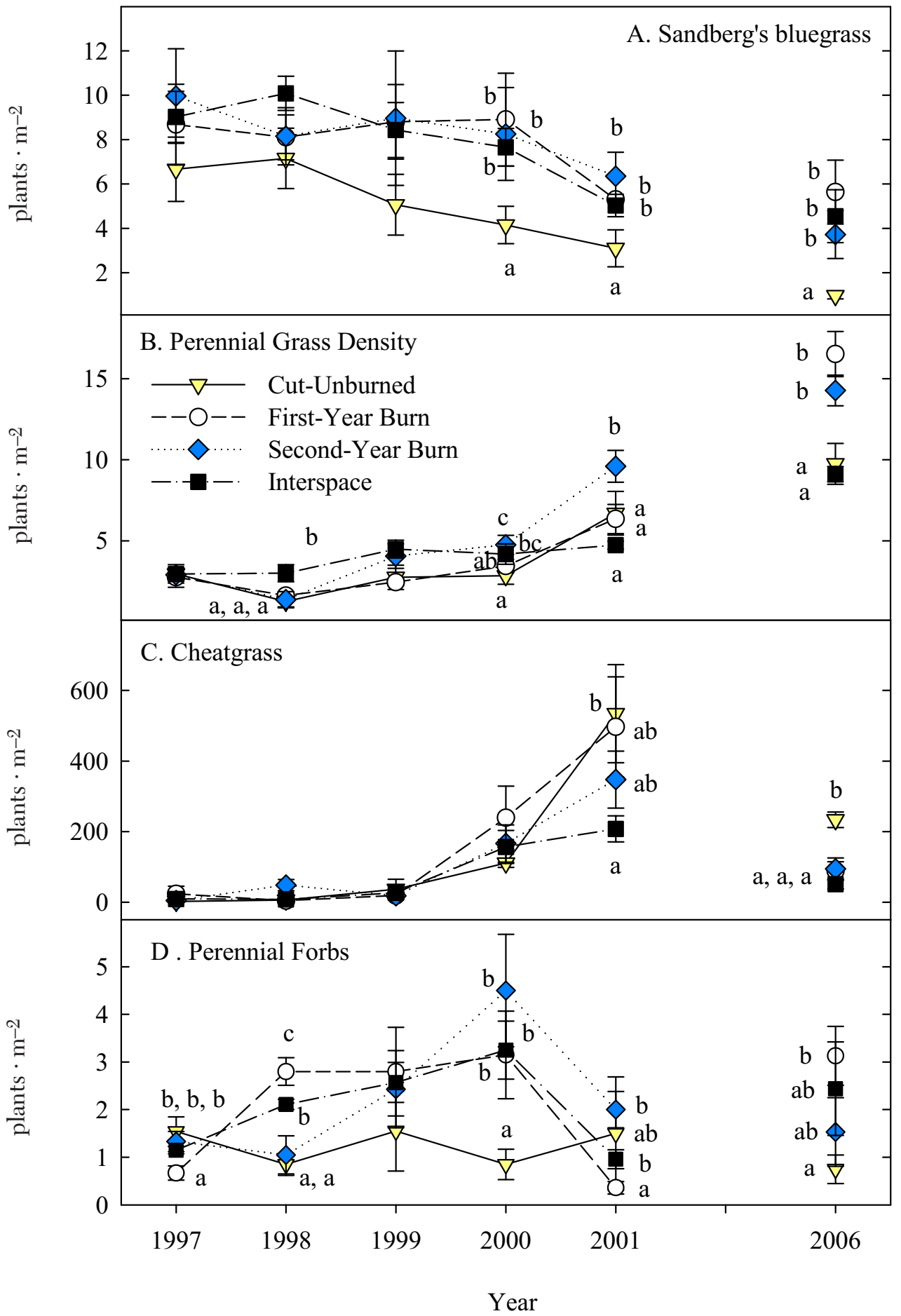

Fig. 5. Functional group densities (plants $\cdot \mathrm{m}^{-2}$ ) for the debris treatments (1st-year burn, 2nd-year burn, cutunburned) and interspace on Steens Mountain, Oregon: A, Sandberg's bluegrass; B, perennial grasses; C, cheatgrass; D, perennial forbs. Data are presented as means with bars representing one standard error. Significant differences $(P<$ 0.05 ) among treatments for the response variables are indicated by different lowercase letters. 


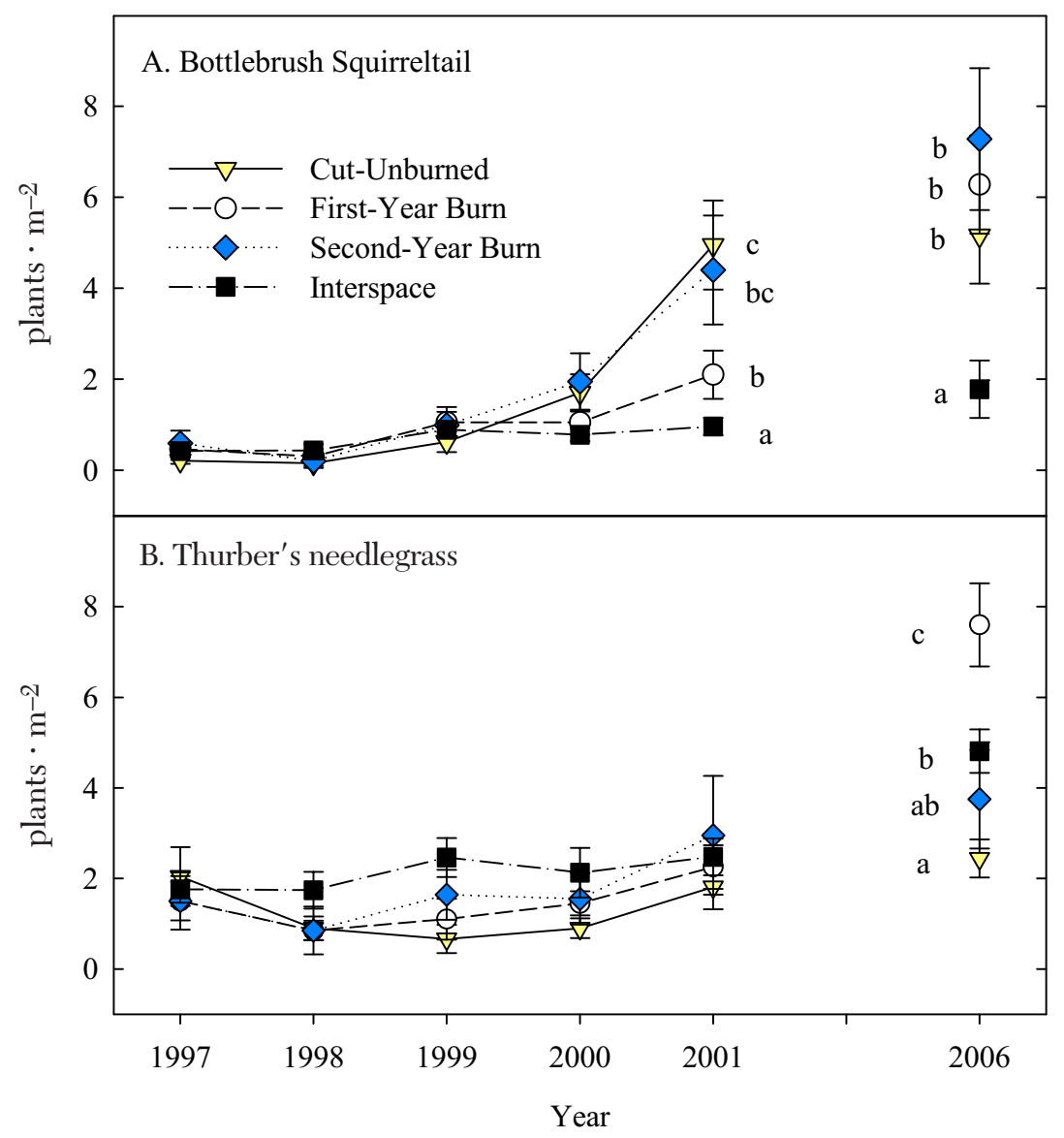

Fig. 6. Densities (plants $\cdot \mathrm{m}^{-2}$ ) of bottlebrush squirreltail (A) and Thurber's needlegrass (B) for the debris treatments (1st-year burn, 2nd-year burn, cut-unburned) and interspace on Steens Mountain, Oregon. Data are means with bars representing one standard error. Significant differences $(P<0.05)$ among treatments for each response variable are indicated by different lowercase letters.j

forb densities were variable across time, and no consistent pattern emerged among the treatments (Fig. 5D).

\section{Species Response}

Species composition was influenced by treatment. Year $\times$ treatment interactions were significant for densities of bottlebrush squirreltail, bluebunch wheatgrass, and Thurber's needlegrass; and they were also significant for cover of several annual forb species (Table 2). Other species only displayed significant year and/or treatment effects (cover and/or density).

Squirreltail densities increased in the cutunburned, 1st-year burn, and 2nd-year burn treatments such that density values in those treatments were all greater than density in the interspace by 2006 (Fig. 6A). At the end of the study, density of Thurber's needlegrass was greater in the 1st-year burn than it was in all other treatments (Fig. 6B). The interspace had greater density of Thurber's needlegrass than the cut-unburned treatment. Bluebunch wheatgrass density increased in all treatments over time (Table 2). By 2006, bluebunch wheatgrass density was greater in the 1st-year burn than in the cut-unburned treatment. Cover of Thurber's needlegrass and bluebunch wheatgrass began to differ among treatments by the second and third year after cutting, respectively (Figs. 7A, 7B). In 2006, Thurber's needlegrass cover was greater in the interspace and 1st-year burn treatment than in the cutunburned and 2nd-year burn treatment. Bluebunch wheatgrass cover was lower in the cut-unburned treatment than in all other 


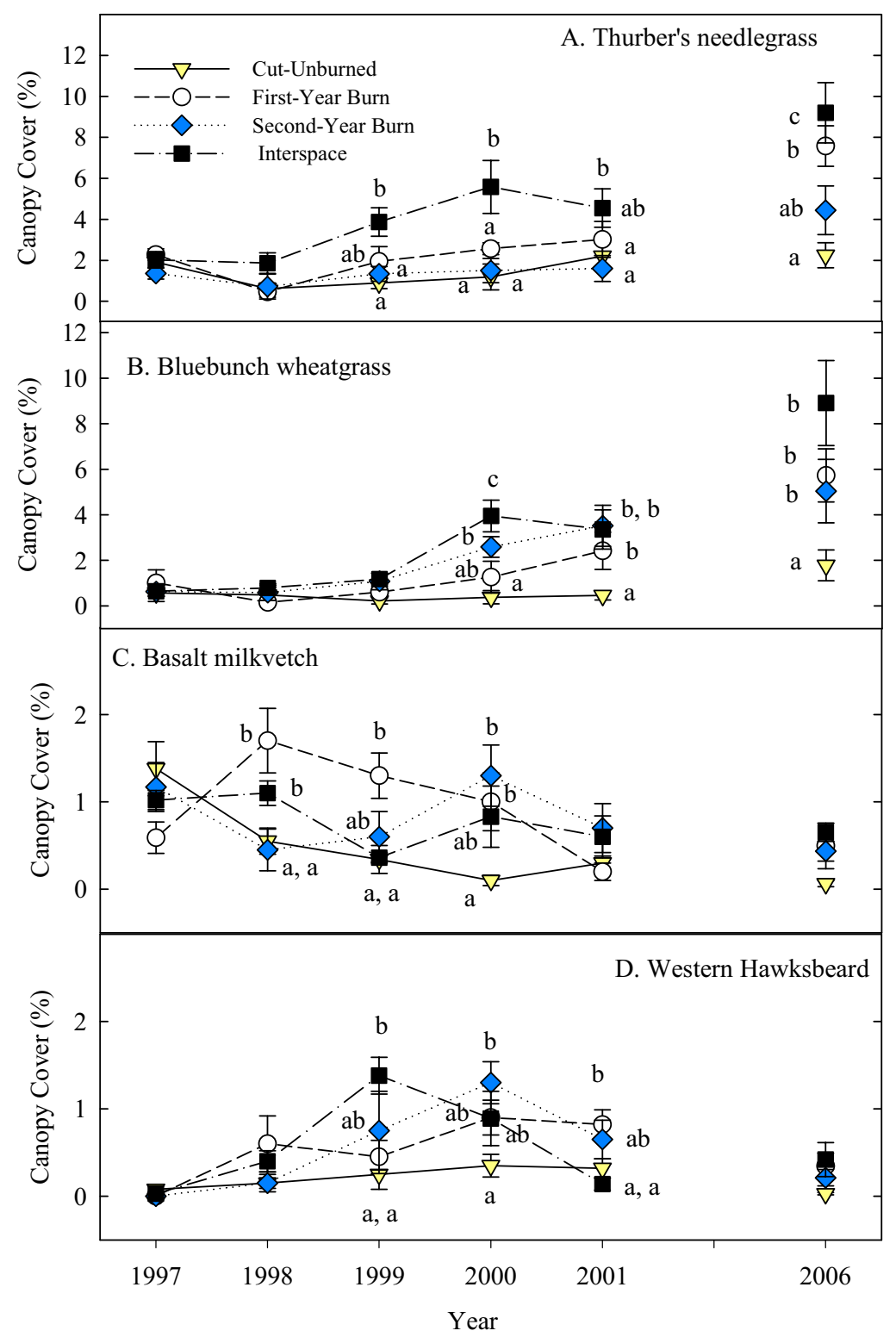

Fig. 7. Cover of Thurber's needlegrass (A), bluebunch wheatgrass (B), basalt milkvetch (C), and western hawksbeard (D) for the debris treatments (1st-year burn, 2nd-year burn, cut-unburned) and interspace on Steens Mountain, Oregon. Data are means with bars representing one standard error. Significant differences $(P<0.05)$ among treatments for each response variable are indicated by different lowercase letters.

treatments by the fourth growing season after cutting (2001).

Cover of basalt milkvetch (Fig. 7C) and western hawksbeard (Crepis occidentalis Nutt.) (Fig. 7D) are illustrative of cover and density dynamics of many other perennial forb species (Table 2). Treatment differences for perennial forb species developed mainly within the first
3-4 years after cutting. Cover of basalt milkvetch and hawksbeard were less in the cutunburned treatment than they were in one or more of the other treatments between 1998 and 2001. By 2006, no differences in cover for these species were found among the treatments. Other perennial forb species developing similar patterns for cover and/or 
density were pale agoseris (Agoseris glauca [Pursh] Raf.), Donnell's lomatium (Lomatium donnelli Coult. \& Rose), tailcup lupine (Lupinus caudatus Kell.), and mariposa lily (Calochortus macrocarpus Dougl).

Annual forb species developed specific responses to the treatments (Table 2). Cover of pale alyssum, a nonnative species, was lower in the cut-unburned treatment compared to the other treatments, particularly in 2006 (Fig. 8A). Epilobium (Epilobium paniculatum Nutt.) and Microseris (Microseris gracilis Hook.) had greater cover in the interspace in the final 4 years of measurement compared to the cutunburned and cut-and-burn treatments (Table 2 ). Treatment differences of other annual forbs were transient and were mainly detected within the first 4 years post-cutting. Cover of prickly lettuce (Latuca serriola L.; Fig. 8B) and tansy-mustard (Descurainia pinnata [Walt.] Britt.; Table 2) were greater in the cut-unburned treatment than in the other treatments in the third year after cutting (2000). Two forbs, line-leaf phacelia (Phacelia linearis [Pursh] Holz; Fig 8C) and sinuate gilia (Gilia intermedia Dougl.; Table 2) had greater cover in the 1st-year burn treatment than in the other treatments in 1999 and 2000.

\section{Burn Severity}

Weather conditions were different between the 2 burn treatments. Air and soil temperatures tended to be lower and humidity and wind speed greater and more variable in the 2nd-year burn compared to the 1st-year burn (Table 1). Soil and litter water content, however, did not differ appreciably between the 2 burns, though soils and ground litter in the 2nd-year burn were frozen. By our criteria, burning in winter was effective at removing aboveground light fuels (juniper leaves up to 1-hour fuels); however, heavier fuels (>10hour fuels) and much of the juniper leaf litter contacting the ground were not consumed by fire. Winter burning reduced but did not eliminate western juniper fuels. As a result it was difficult to apply a severity rating to either burn treatment. Consumption of surface litter was light in both burn treatments. In the 1styear burn treatment, cover of juniper litter was reduced by $30.3 \% \pm 4.7 \%$ after fire and in the 2 nd-year burn, litter cover was reduced by $12 \% \pm 2.3 \%$ after fire (Fig. 3B). Aboveground consumption of cut juniper removed all mate- rial up to the 10-hour fuels category, which would indicate a moderate severity rating. The fire severity index did not prove useful for predicting mortality of perennial bunchgrasses. Neither burn treatment resulted in a decline in Sandberg's bluegrass density after fire (Fig. 5A). Perennial grass densities decreased by $41 \%$ in the 1st-year burn between 1997 and 1998 (Fig. 5B). Yet, over the same time period, perennial grass densities in the cut-unburned and 2nd-year burn (not yet burned) treatments declined by greater than $50 \%$. In the 2 nd-year burn, perennial grass densities increased 2fold between 1998 and 1999 (first growing season after fire).

\section{Discussion}

\section{Effects of Burning}

The burning of cut western juniper trees in the winter had a long-term, positive effect on the recovery of native herbaceous perennials when compared to the effect of leaving cut trees unburned and in place. Though differences among the 3 cutting (unburned and burned) treatments were detected in early succession (1998-2001), the results highlight the importance of evaluating disturbance impacts over long time periods. Differences among the treatments for perennial bunchgrasses, Sandberg's bluegrass, and cheatgrass response variables, as well as understory composition, became much more obvious by 2006 , ten years after treatments were applied. Herbaceous cover, perennial grass cover, and perennial grass densities were 1.5-2 times greater in the 1st-year and 2nd-year burn treatments than in the cut-unburned treatment. Burning cut trees did not limit the establishment of cheatgrass in early succession (1999-2001) but did limit the duration of high cheatgrass cover and density. The increases in perennial grass density and cover in the burned treatments suggest that perennial suppression of cheatgrass was a primary factor for cheatgrass decline by 2006. In contrast, the cut-unburned treatment retained high levels of cheatgrass through the end of the study. Thus, we accepted our hypotheses that winter burning of cut western juniper would result in more rapid and larger increases in perennial herbaceous cover/density and lower cheatgrass cover/density compared to the results of leaving cut trees unburned. 


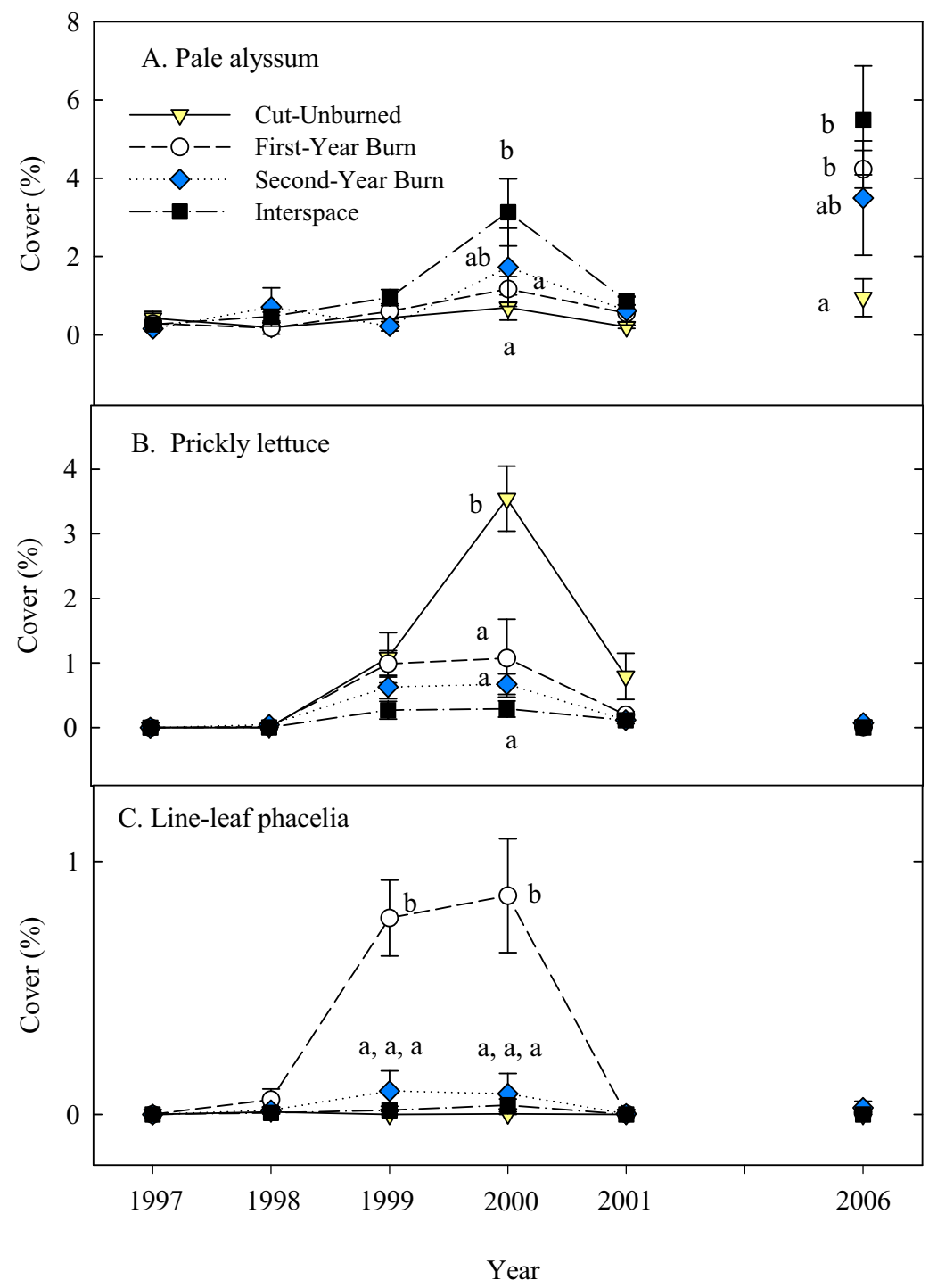

Fig. 8. Cover of pale alyssum (A), prickly lettuce (B), and line-leaf phacelia (C) for the debris treatments (1st-year burn, 2nd-year burn, cut-unburned) and interspace on Steens Mountain, Oregon. Data are means with bars representing one standard error. Significant differences $(P<0.05)$ among treatments for each response variable are indicated by different lowercase letters.

Our results contrast with herbaceous response reported by Haskins and Gehring (2004) following burning of pinyon-juniper slash in Arizona. They measured 4-fold higher abundance of invasive annuals in burned slash areas compared to unburned slash and suggested that slash burning may be detrimental to native perennial plant recovery in treated pinyonjuniper woodlands. Haskins and Gehring (2004) did not provide burning conditions or time of burn in their article. The timing or conditions under which cut trees or slash/debris are burned appears to be an important determinant of post-fire herbaceous response. For example, burning of cut western juniper and trees in quaking aspen stands in the fall (dry soils and fuels) severely impacted the understory, shifting understory composition from dominance by herbaceous perennials (largely eliminated by fire) to native and nonnative invasive annuals and biennials (Bates et al. 2006). In aspen stands where cut juniper was burned in spring 
(wet/frozen soils, higher fuel moisture), there was no mortality of herbaceous perennials, and after 3 years, perennial herbaceous cover and richness were nearly 2 -fold greater in treatments burned in spring than those burned in fall.

We had hypothesized that burning cut juniper would not result in a reduction of perennial bunchgrass density compared to cutunburned trees. There was a decrease in perennial bunchgrass density in the 1st-year burn, though the reductions were not different than those for unburned trees (cutunburned and 2nd-year burn) the first growing season (1998) after treatment (Fig. 5B). This suggests that smothering by unburned cut juniper had about the same effect on perennial grasses as did burning the first year after cutting. The 2nd-year burn removed smaller amounts of juniper leaf litter (Fig. 3B) and perennial grass density tripled (Fig. 5B) in the year of the burn (1999). We suspect that saturated, frozen surface litter and soils limited heat penetration into the soil, which likely limited mortality of grass seeds or seedlings. This would explain why perennial grass density increased in the 2nd-year burn in 1999.

An interesting aside was the population dynamics of cheatgrass. Despite drought conditions, cheatgrass increased between 1999 and 2001. The subsequent decline of cheatgrass in 2006 occurred in an above-average precipitation year. The decline in cheatgrass may have resulted from (1) less favorable seedbed conditions as litter was incorporated into the soil and exposure increased; (2) reduced soil nutrient availability; and (3) competition from perennial grasses increased. The continued increase of perennial grass cover and density during the drought years suggests that perennial suppression of cheatgrass was a primary factor for cheatgrass decline.

\section{Effects of Cut Juniper}

Several studies of other species of juniper indicate that establishment and productivity of herbaceous plants are negatively correlated to juniper litter depth (Jameson 1966, Schott and Pieper 1985, Horman and Anderson 2003) and potential allelopathic compounds contained in litter (Jameson 1970). Horman and Anderson (2003) concluded that allelopathic compounds are species specific but rarely reach toxic levels in natural settings because they decom- pose quickly. We did not test for allelopathic or litter depth effects on herbaceous plants; however, it appears that juniper leaf litter that fell from cut trees influenced plant composition and dynamics among the treatments. Felled trees and subsequent leaf drop created litter layers ranging from a shallow surface covering to a depth of several inches.

The higher amounts of juniper litter cover (Fig. 3B) in the cut-unburned treatment were associated with the following plant community changes: (1) perennial bunchgrass composition shifted from primarily Thurber's needlegrass and bluebunch wheatgrass to bottlebrush squirreltail; (2) there was limited establishment or reduced presence of several species, including Thurber's needlegrass, Sandberg's bluegrass, and most perennial forbs; and (3) since the fourth growing season after juniper cutting, cheatgrass dominated the herbaceous component. Horman and Anderson (2003) indicated that emergence of cheatgrass and native grass species was suppressed by increasing juniper litter depth. However, in our study and others (Young et al. 1985, Miller et al. 2005, Bates et al. 2007a), cheatgrass has demonstrated the ability to increase in areas of juniper litter deposition about 4-5 years after western juniper control. Squirreltail density also increased in cut-unburned treatment in spite of cheatgrass dominance. Others have reported increases in squirreltail in annual grass-dominated areas (Hironaka and Tisdale 1963, Bates et al. 2006). Cover of squirreltail in the cutunburned treatment was less than in the other treatments, which may indicate that squirreltail growth was being suppressed by the higher juniper litter cover and/or continued dominance of cheatgrass. Other perennial grass species and native forbs were reduced or did not increase under cut-unburned juniper, which suggested suppression by juniper litter and/or interference by cheatgrass.

However, a certain level of juniper litter cover appears to have been beneficial to establishment of perennial bunchgrasses, as their densities were $60 \%-80 \%$ greater in the 2 burned treatments than they were in the interspace (lowest litter cover) and the cut-unburned treatment (high amounts of litter; Fig. 5B). Thurber's needlegrass established most successfully in the 1st-year burn treatment where litter cover was lower than in the other cut treatments but greater than in the interspace. 
As a group, perennial and annual forbs preferred interspace and cut-and-burn treatments. On this site the potential for forbs to be a significant component of the understory is low, as perennial grasses dominate the understory following juniper control (Bates et al. 2005). On sites where native forbs are a greater component of the understory, there may be greater potential for these species to increase after burning cut juniper (Miller et al. 2005).

\section{Implications for Restoration and Management}

Mechanical control of western juniper and other pinyon-juniper species is an effective method to restore herbaceous productivity and diversity in rangelands of the western United States (Miller et al. 2005). In this study, we did not compare the juniper removal treatments to untreated woodland. However, based on earlier comparisons between cut and uncut woodlands on this site (Bates et al. 2000, 2005, 2007a), juniper cutting and cutting and burning were effective at increasing understory cover and density. Without shrubs or juniper present, herbaceous cover potential on this site fell between $25 \%-30 \%$ and potential perennial grass densities ranged between 8 and 10 plants $\cdot \mathrm{m}^{-2}$ (Bates et al. 2005). From the earlier studies, recovery of herbaceous cover requires 2-4 years. All treatments except interspace were at potential cover levels by 2001, the fourth year after cutting. In 2006 the cutunburned treatment was the only treatment below 25\% herbaceous cover. Perennial grass densities reached site potential by the fourth year after treatment in the 1st-year burn treatment. Perennial grass density in the other treatments reached potential between 2002 and 2006.

As mechanical treatment of invasive western juniper woodlands has become increasingly common, so have concerns about large amounts of western juniper debris and slash generated by control operations. After cutting on juniperdominated sites, $20 \%$ to nearly $100 \%$ of an area may be covered with cut juniper and slash (Miller et al. 2005). Although there is the potential for western juniper to be used as a biofuel, for many areas distance and accessibility limit economic viability. Thus, for many restoration treatments, mechanically treated juniper will need to be managed on site. In some cases it may be best to leave cut juniper in place to retain nutrients stored in litter (Miller et al. 2005) and to reduce soil erosion (Hastings et al. 2003). Seeded perennial grass establishment may be enhanced under cut trees and slash, particularly on more-arid sites (Eddleman 2002). However, as demonstrated in our study and others (Bates et al. 1998, 2007a, Brockway et al. 2002) cut juniper and juniper debris accumulations alter plant composition and may slow native perennial recovery. Cut juniper and slash promote dominance by undesirable annual grasses (Young et al. 1985, Bates et al. 2005). Brockway et al. (2002) found that the smothering effects on herbaceous diversity by debris could be mitigated by scattering one-seed juniper (Juniperus monosperma) slash. The scattering of western juniper slash often more than triples treatment costs and may not be practical for large-scale applications in these woodlands.

Cheatgrass presence remains a concern in western juniper woodlands, as it has shown potential to increase rapidly and dominate the understory following western juniper control (Quinsey 1984, Evans and Young 1985). The plant community in our study is an ecotone where annual grass infestation may or may not pose a threat following disturbance (Miller et al. 2000). Eliminating cheatgrass from these communities is not practical, but our results indicate that designing treatments that alter or take away preferred establishment sites have the potential to reduce annual grass influence. Svejcar (2003) and Sheley and Krueger-Mangold (2003) recommended that managers consider site availability, species availability, and species performance when developing strategies to reduce weed infestations. Targeting establishment sites for weeds may redirect successional trajectories so that desired outcomes are achieved (Svejcar 2003). Because areas of juniper litter accumulation provide favorable sites for establishment and development of cheatgrass, an obvious solution to reduce cheatgrass establishment is to remove cut juniper trees or debris. Brockway et al. (2002) demonstrated that mechanical removal of cut pinyon-juniper increased plant diversity on New Mexico rangelands. Where mechanical removal may not be practical, our results suggest that winter burning of cut juniper trees and debris has the potential for enhancing native plant community recovery. The speed of response may depend on site potential. In 
aspen woodlands, early spring burning of cut juniper resulted in no measurable mortality of native plants, and by the third year after treatment herbaceous cover had increased by $300 \%$ and species richness by $50 \%$. Recovery of native plant vegetation in the present study did not proceed as rapidly. However, our results demonstrated that burning cut western juniper in winter has the potential to speed recovery of the native plant community and limit the duration of high cheatgrass presence.

Winter burning under the conditions described in the study (Table 1) is limited to the first 2-3 years after tree cutting. From observation, by the third year after cutting, most of the juniper leaves have fallen to the ground and burning in winter is not practical unless surface litter on the ground is dry. However, as discussed previously, burning cut western juniper when surface litters are dry severely impacts native herbaceous vegetation and potentially may permit cheatgrass or other weeds to dominate the site (Bates et al. 2006, $2007 \mathrm{~b}$ ) and subsequently open these areas up to dominance by nonnative weeds. Given the high potential for damaging native plants and stimulating weed response by burning when litter and other fuels are dry, the best option might be to leave cut western juniper in place. In the other long-term studies on this site there was a period of cheatgrass dominance beneath cut trees; however, with patience native perennials largely replaced cheatgrass after about 13 years (Bates et al 2005, 2007a). In our study area, if current vegetation trends continue, cheatgrass will likely continue to decline in the unburned treatment as native perennial grasses increase.

\section{ACKNOWLEDGMENTS}

We are especially grateful to Fred Otley of Otley Brothers, Inc., for the use of their property for the study. Completion of field measurements was accomplished with the assistance of a host of undergraduate summer range technicians. Thanks are due to Jane Mangold, Kirk Davies, and 2 anonymous reviewers for their editorial comments and suggestions on earlier drafts of the manuscript.

\section{Literature Cited}

Bates, J.D., R.F. Miller, AND K.W. DAVIES. 2006. Restoration of quaking aspen woodlands invaded by western juniper. Rangeland Ecology and Management 59:8897.

Bates, J.D., R.F. Miller, and T.J. SvejCar. 1998. Understory patterns in cut western juniper (Juniperus occidentalis spp. occidentalis Hook.) woodlands. Great Basin Naturalist 58:363-374.

2000. Understory dynamics in cut and uncut western juniper woodlands. Journal of Range Management 53:119-126.

2005. Long-term successional trends following western juniper cutting. Rangeland Ecology and Management 58:533-541.

2007a. Long-term spatial dynamics in a cut western juniper woodland. Western North American Naturalist 67:549-561.

Bates, J.D., R. Miller, T. Svejcar, K. Davies, F. Pierson, S. Hardegree. 2007b. Western juniper control studies: EOARC research report [online]. Eastern Oregon Agricultural Research Center, Station Report, Burns. 57 pp. Available from: http://oregonstate.edu/ dept/EOARC/abouthome/scientists/jon.htm

Bates J., T. SvejCar, and R.F. Miller. 2002. Effects of juniper cutting on nitrogen mineralization. Journal of Aridland Environments 51:221-234.

Brockway, D.G., R.G. Gatewood, and R.B. Paris. 2002. Restoring grassland savannas from degraded pinyonjuniper woodlands: effects of mechanical overstory reduction and slash treatment alternatives. Journal of Environmental Management 64:179-197.

Buckhouse, J.C., and J.L. Mattison. 1980. Potential soil erosion of selected habitat types in the high desert region of central Oregon. Journal of Range Management 33:282-285.

BurkhardT, J.W., and E.W. Tisdale. 1969. Nature and successional status of western juniper vegetation in Idaho. Journal of Range Management 22:264-270.

Eddleman, L. 2002. Establishment and development of broadcast seeded grasses under western juniper slash. Pages 36-42 in Range Field Day Progress Report. Range Science Series Report \#5, Department of Rangeland Resources, Oregon State University and Eastern Oregon Agricultural Research Center, Corvallis.

Evans, R.A., AND J.A. Young. 1985. Plant succession following control of western juniper (Juniperus occidentalis) with Picloram. Weed Science 33:63-68.

GiFFORD, G.F. 1981. Impact of burning pinyon-juniper debris on select soil properties. Journal of Range Management 34:357-359.

Haskins, K.E., AND C.A. GEHRING. 2004. Long-term effects of burning slash on plant communities and arbuscular mycorrhizae in a semi-arid woodland. Journal of Applied Ecology 41:379-388.

Hastings, B.K., F.M. Smith, AND B.F. Jacobs. 2003. Rapidly eroding pinyon-juniper woodlands in New Mexico: response to slash treatments. Journal of Environmental Quality 32:1290-1298.

HironaKa, M., and E.W. Tisdale. 1963. Secondary succession in annual vegetation in southern Idaho. Ecology 44:810-812.

Horman, C.S., AND V.J. ANderson. 2003. Understory species response to Utah juniper litter. Journal of Range Management 56:68-71.

JaCOBS, B.F., AND R.G. GatewOOd. 1999. Restoration studies in degraded pinyon-juniper woodlands of north-central New Mexico. Pages 294-298 in S.B. Monsen and R. Stevens, compilers, Proceedings: 
ecology and management of pinyon-juniper communities within the Interior West, Sept 15-18, 1997, Provo, Utah. RMRS-P-9, Rocky Mountain Research Station, USDA Forest Service, Ogden, UT. 411 pp.

Jameson, D.A. 1966. Pinyon-juniper litter reduces growth of blue grama. Journal of Range Management 19: 214-217.

1970. Degradation and accumulation of inhibitory substances from Juniperus osteosperma. Plant and Soil 33:213-224.

Josiatis, R.M. 1990. The effects of western juniper occupancy on changes in soil characteristics in relation to shrub and grass establishment in Owyhee County, Idaho. Master's thesis, University of Idaho, Moscow. $84 \mathrm{pp}$.

Miller, R.F., J.D. Bates, T.J. Svejcar, F.B. Pierson, and L.E. Eddleman. 2005. Biology, ecology, and management of western juniper. Technical Bulletin 152, Oregon State University Agricultural Experiment Station, Corvallis. 77 pp.

MilleR, R.F., AND J.R. Rose. 1995. Historic expansion of Juniperus occidentalis (western juniper) in southeastern Oregon. Great Basin Naturalist 55:37-45.

Miller, R.F., T.J. SvejCaR, and J.R. Rose. 2000. Impacts of western juniper on plant community composition and structure. Journal of Range Management 53:574585 .

Miller, R.F., M. Willis, J. Rose, D. Reinkensmeyer, AND B. ANTHONY. 1999. Effects of community structure on avian populations in juniper woodlands and shrub steppe. Pages 106-111 in Range Field Day 1999 Progress Report. Special Report 1002, Department of Rangeland Resources, Oregon State University and Eastern Oregon Agricultural Research Center, Corvallis.

Noson, A.C., R.A. Schmitz, and R.F. Miller. 2006. Influence of fire and juniper encroachment on birds in high-elevation sagebrush steppe. Western North American Naturalist 66:343-353.
Peterson, R.G. 1985. Design and analysis of experiments. Marcel Dekker, Inc., New York. 429 pp.

Pierson, F.B., J.D. Bates, T.S. Svejcar, and S. Hardgree. 2007. Long-term changes in runoff and erosion after cutting western juniper. Range Ecology and Management 60:285-292.

QuiNSEY, S.D. 1984. Fire and grazing effects in western juniper woodlands of central Oregon. Master's thesis, University of Washington, Seattle. $125 \mathrm{pp}$.

Roberts, C., AND J.A. Jones. 2000. Soil patchiness in juniper-sagebrush-grass communities of central Oregon. Plant and Soil 223:45-61.

SAS Institute, Inc. 2002. User's guide. Release 8.03. SAS Institute, Inc., Cary, NC.

SCHOTT, M.R., AND R.D. PiePER. 1985. Influence of canopy characteristics of one-seed juniper on understory grasses. Journal of Range Management 38:328-331.

Sheley, R., and J. Krueger-Mangold. 2003. Principles of restoring invasive plant-infested rangelands. Weed Science 51:260-265.

SveJCAR, T. 2003. Applying ecological principles to wildland weed management. Weed Science 51:266-270.

Vaitkus, M., ANd L.E. Eddleman. 1987. Composition and productivity of a western juniper understory and its response to canopy removal. Pages 456-460 in R.L. Everett, editor, Proceedings: Pinyon-Juniper Conference. General Technical Report INT-215, USDA Forest Service, Intermountain Research Station, Ogden, UT. 581 pp.

Wall, T., R.F. Miller, and T.S. SvejCar. 2001. Juniper encroachment into aspen in the northwest Great Basin. Journal of Range Management 54:691-698.

Young, J.A., R.A. Evans, AND C. Rimby. 1985. Weed control and revegetation following western juniper control. Weed Science 33:513-517.

Received 13 December 2007 Accepted 9 June 2008 